\title{
1: 158364633-158379375
}

National Cancer Institute

\section{Source}

National Cancer Institute. 1:158364633-158379375. NCI Thesaurus. Code C42253.

Physical location of FCGR2C_Gene 